\title{
Ter mundus accipit infinitum: The Dogmatic Coordinates of Schleiermacher's Trinitarian Treatise
}

\author{
Paul J. DeHart, Associate Professor of Theology, The Divinity School, \\ Vanderbilt University, $41121^{\text {st }}$ Avenue South, Nashville, Tennessee 37240, USA, \\ p.dehart@Vanderbilt.Edu
}

Does Schleiermacher's Christian Faith contain what the older dogmaticians would have called a treatise de trinitate? Many contemporary theologians, even those having some familiarity with Schleiermacher's masterpiece, might be hard pressed to answer the question. In view of the fact that Schleiermacher's dogmatics does indeed contain a quite detailed, though highly compressed, discussion of the doctrine of the Trinity, clearly labeled as such and showing evidence of exceedingly careful thought, this state of affairs is remarkable. To account for it is already to begin to search for a way beyond the utter neglect with which Schleiermacher's thoughts on the Trinity have usually been met since the mid-nineteenth century.

Initially, one can doubtless point to the fact that the single figure most responsible for bringing classical Trinitarian ideas back into the center of more recent Protestant theological discussion was Karl Barth, and that his vastly influential theological stance conditioned many minds to connect the retrieval of the Trinity with the rejection of any "liberal" approach to dogmatics like Schleiermacher's. Refusing Barth's stance but accepting the terms of the debate as he set them, liberal theologians working against the grain of Barthian trends might often champion Schleiermacher, but they usually had little use for the doctrine of the Trinity, and therefore tended to underplay or ignore the latter's discussions of the issue. Among Protestant theologians of the previous century, and to some degree even today, those invested in the doctrine of the Trinity were not interested in Schleiermacher, and those intrigued by Schleiermacher had no interest in the Trinity.

Ironically, members of both camps could claim that their neglect of Schleiermacher's Trinitarian notions was no mere reflex of their mutually opposed biases, for that neglect was, it could be assumed, already inscribed into Schleiermacher's own dogmatics. Didn't he, by his notorious "relegation of the dogma to an appendix" (to use the endlessly repeated words of an influential older study), quite deliberately place himself, for better or worse, quite outside the arena of Trinitarian discussion? ${ }^{1}$ It is perhaps the persistence of this structural assessment, rather than the broader theologi-

\footnotetext{
1 Claude WELCH, In This Name (New York: Scribner's, 1952), 4.
} 
cal prejudices associated with the increasingly effaced battle lines of the previous century, which continues to be a serious hindrance to closer investigation of Schleiermacher's Trinitarian ideas. ${ }^{2}$

As signaled by the just cited phrase, it has proven almost irresistible to conclude from the location of Schleiermacher's explicit discussion of the Trinity (a discrete and relatively brief section at the end of the work) that Schleiermacher's interest in the doctrine must have been perfunctory, its role in his dogmatics marginal. But however natural or obvious this judgment may seem, it is a superficial one. ${ }^{3}$ The paper which follows intends to contribute to the ongoing reassessment of Schleiermacher's Trinitarian thought by interpreting that concluding section in a way which contests this tendency to isolate it, to detach it from the broader themes of the dogmatics. ${ }^{4}$ The paper will emphasize precisely how Schleiermacher's entire

2 The structural question here is concerned with Schleiermacher's own conception of the Trinity, and must be distinguished from the issue of the influence of Schleiermacher on the way later theologians handled the doctrine. Maintaining this distinction is important in assessing Welch's claim, for example, that Schleiermacher's thought was one of the factors "most directly responsible for subsequent questioning of the importance and validity of the doctrine of the Trinity." WELCH (see above, n. 1), 3. One might concede Welch's point by saying that some ideas or emphases of Schleiermacher's concerning the epistemology of faith and the nature of doctrinal language, as they were widely taken up and internalized by many nineteenth-century Protestant theologians, probably did contribute to a neglect of the Trinity (although it is just as arguable that the genuine roots of that neglect run much further back in history). But it is essential to recognize, for the purposes of the present discussion, that such an outcome does not in itself prove anything about the role or importance of Trinitarian ideas for Schleiermacher himself; indeed, it is arguable that the ensuing dissolution of Trinitarian discourse was contrary to Schleiermacher's own intentions. Otherwise put, the fact that some of Schleiermacher's ideas contributed in some way to the marginalization of the Trinity among later theologians does not imply that Schleiermacher's own theology ignored or denigrated it.

3 As a start, it must be firmly maintained that any reference to the concluding Trinitarian discussion of the Glaubenslehre as an "appendix", as instanced by Welch and countless other commentators, simply cannot be taken as a neutral description: it already implies a polemical comment on Schleiermacher's Trinitarianism (a misleading and prejudicial one, as this paper will suggest). As a translation it is simply erroneous, in light both of the function of that section, and of the title Schleiermacher actually gave it (it is called the 'Schluss', the 'conclusion', in both editions).

4 The concern here is with exegesis of Schleiermacher's own texts, and not with discussions in the secondary literature, although it can be remarked in passing that direct treatments of his Trinitarian thought have been relatively sparse. Indeed, a quick survey would reveal that past treatments of Schleiermacher's doctrine of God proper seldom broach the issue of the Trinity, tending to focus either on the general relation of God and world or else on Schleiermacher's rethinking of the divine attributes. Even quite penetrating discussions can evade the whole subject with ease, but this becomes understandable once it is grasped that Schleiermacher does not see the doctrine of the Trinity as part of the doctrine of God, but rather more the reverse: his doctrine of God is one element within his Trinitarian conception. There are promising recent signs of more detailed interest in Schleiermacher's Trinitarian ideas as such. Especially noteworthy is the inclusion of Francis Schüssler FIORENZA's fine overview ("Schleiermacher's understanding of God as triune") in the Cambridge Companion to Friedrich Schleiermacher, ed. by Jacqueline MARINA (Cambridge, Cam- 
discussion of the Trinity is intricately linked with, in fact substantively derivative of, certain earlier sections of his dogmatics; it is a kind of metadoctrine, coordinated with and coordinating the central Schleiermacherian accounts of how Christian redemption functions. This reconnection of the Trinity with other doctrines will have the additional purpose of uncovering the basic logic of the doctrine as Schleiermacher sees it: the threefold reception of the infinite being of the creator within the confines of the finite created order.

The first section will examine the close link between Schleiermacher's notion of redemption and the ontology of the incarnation. The second and third sections will then examine that ontology in some detail as a complex and profound conceptualization of Paul's affirmation that "God was in Christ". The fourth section will show how Schleiermacher then extends and transforms that conception of incarnation in order to explain by analogy the redeeming presence of the Holy Spirit in the church. The fifth section will then indicate how attention to these previous discussions helps to deliver a more satisfactory verdict on the question of the dogmatic function of the doctrine of the Trinity in Schleiermacher. A sixth and final section will return to the question with which the essay began, that of the "concluding" location of Schleiermacher's treatise, in order to reflect on what he thought he had achieved there, as well as what lessons contemporary theology might begin to draw from it.

\section{I.}

The doctrine of the Trinity in Schleiermacher centers on the way God is present and active in redemption, at least when redemption is understood (as Schleiermacher claims to do) in classical or "ecclesial" terms. Roughly speaking, this means conceiving redemption as union with God, by means of the Holy Spirit joining the believer to Jesus Christ as the incarnate Word. God, in other words, is joined originally to the human being Jesus, and is joined secondarily or derivatively (through the Spirit) to the human beings making up the believing community. Thus the conceptual key to Schleiermacher's reformulation of the ecclesial doctrine of redemption is to be found in his notion of a genuine union between the divine being and human nature, and in order to fathom what this means for him it will be necessary to look carefully at one of the most dense and suggestive passages in his dogmatics, the second paragraph of proposition 94 of the second edition.

bridge University Press, 2006, 171-88). The devotion of an entire chapter to this topic in a basic introduction to Schleiermacher's thought would have seemed unthinkable until recently. 
That any adequate grasp of the Christian message depends upon the proper assessment of Christ's constitution is a point made here in no uncertain terms. For it is the peculiar dignity of Christ's person, the utterly unique ontological status of his selfhood, which makes it possible to grant him the exclusive title of "the" redeemer, to ascribe to him the completion of the creation of humanity, to see in him the founder and the continued source of power of a religious community which is destined to overtake and absorb every other religious community: to do justice to all of this, Schleiermacher asserts, demands nothing less than the affirmation of God's "existence" [Sein] in Christ ( $\$ 94.2$; CG II 54 [CF 386])..$^{5}$ A casual reading can easily miss the seriousness with which Schleiermacher is prepared to take this language, and the effort he takes to explicate it. The weightiness of the claim can only be grasped against the background of the austere and, it could even be said, rigorously "classical" manner in which Schleiermacher understands the utter transcendence of the divine creator in relation to all finite, spatio-temporal reality. His stringent affirmations of the divine

5 All parenthetical references in the text are to proposition number and paragraph number of the second edition (1830/31) of the Glaubenslebre, followed by the volume and page number of the German ('CG') and page number of the English ('CF') editions noted below. German: Friedrich SCHLEIERMACHER, Der christliche Glaube: nach den Grundsätzen der evangelischen Kirche im Zusammenhange dargestellt. Zweite Auflage (1830/31) in Kritische Gesamtausgabe, ed. by Hans-Joachim BIRKNER et al., vols. I/13, 1 and I/13, 2, ed. by Rolf SCHAFER (Berlin/ New York: Walter de Gruyter, 2003). English: Friedrich SCHLEIERMACHER, The Christian Faith, transl. by H. R. MACKINTOSH and J. S. STEWART (Edinburgh: T\&T Clark, 1928). Apart from some silent emendations, direct quotations will follow the latter edition. However, two translation decisions made throughout the following discussion should be especially highlighted. Schleiermacher refers repeatedly both to the divine "Sein" and to the divine "Wesen". In the standard English version, the translators are not completely consistent, choosing to render "Sein" as "existence" but sometimes as "being", and "Wesen" as either "being" or as "essence." Although these choices are surely defensible in terms of the shifting contexts in which the words appear, I have thought it best to employ a uniform rendering of "Sein" as "existence" and "Wesen" as "being," omitting the standard version's frequent use of capitalization when these terms are used of God. Although etymologically both of these are nominal forms of the verb "to be," in Schleiermacher's usage the former tends to retain more of a "verbal" feel (suggesting presence as activity), while the latter retains something of a "nominative" heft (suggesting the unity and identity of the divine reality); my choices try to honor these patterns. Granted, translating "Wesen" by "essence" is especially tempting in Trinitarian discussions where "the one divine essence" has by long custom been juxtaposed with "the three persons" as ways of referring to God as one and God as three, respectively. However, speaking of the divine "essence", even in contexts where Schleiermacher is clearly picking up and continuing such earlier dogmatic discussions, could potentially mislead if it suggested a genus or kind standing over against other kinds. His quite justified rejection of any such notion is the source of his sharp criticism of the phrase "divine nature" (Natur) (\$ 96.1; CG II 62-4 [CF 392-3]). The fact that he shortly thereafter in the same section (CG II 66-7 [GF 395]) commends the term "Wesen" as more appropriately used of God than the term "Natur" is all the more reason to avoid any translation of the former which might suggest proximity to the latter. Where the standard English translation has been quoted directly in what follows, it has been altered to bring it into line with the practice just described. 
transcendence force him to specify with great care and precision what it might mean for the divine existence to be "in" the world or "in" Christ.

The conceptual equation which lies at the heart of this notion is stated immediately at the beginning of $\$ 94.2$. To speak of the existence of God in Christ is "completely the same thing" as to ascribe to him an absolutely powerful God-consciousness ( $\$ 94.2$; CG II 55 [CF 387]). ${ }^{6}$ The rest of $\$ 94.2$ is devoted to showing why this is so. The issue is complex, and rooted deeply in the difficulties of Schleiermacher's overall understanding of the relation of Creator to creation. The parallel discussion from the first edition of the Christian Faith $(\$ 116.3$ ) will be cited at some points in order to shed a little more light on the obscurities of Schleiermacher's exposition here. What follows is an interpretive restatement of what is at issue for him in this equating of divine existence in Christ with his unique God-consciousness.

There are two stages to Schleiermacher's explanation. First, insofar as we can speak of an existence of God "in" the world as a whole, it is only possible because there is an existence of God in human nature. Second, insofar as we can speak of an existence of God "in" human nature, it is only possible because of the presence of perfect or absolutely powerful God-consciousness. To put it another way, the presence of God in rational consciousness "mediates" to separate things God's presence in the world as a whole, and the presence of Jesus Christ among human beings "mediates" to them God's (potential) presence in rational consciousness in general. ${ }^{7}$ The two following sections take up each stage in turn.

6 In Schleiermacher's usage concepts such as "God-consciousness", “immediate self-consciousness", and "feeling" indicate elemental factors in what might be called his ontology of subjectivity. What is at issue is the structure of human selfhood as a reality within the world, and not the description of transitory psychological states.

7 The exact phrase "rational consciousness" does not appear in Schleiermacher's texts, but the idea is clearly at work in the key passage of The Christian Faith (\$94.2) under analysis here. It would be misunderstood if it were taken to refer to some special human faculty, like knowledge. In fact, the term "rational consciousness" in Schleiermacher's usage could almost be taken as a synonym for "adult human being". The terms "reason" and "rational" refer to the realm of the spiritual/mental (geistlich) as opposed to the natural. See here the basic definitions laid out in his 1812/13 lectures on philosophical ethics, especially in the "Introduction" to the lectures as a whole, section I, theses 16-18, and section III, theses $39,68-70,78$; and also in "The highest good", Introduction, theses 1-6. F. D. E. SCHLEIERMACHER, Werke: Auswabl in vier Bänden, $2^{\text {nd }}$ ed., eds. Otto BRAUN \& Johannes BAUER (1927; reprint, Aalen: Scientia Verlag, 1967), 2: 247, 249-50, 253-4, 255, 258-9. In English, Friedrich SchleiermaCHER, Lectures on Philosophical Ethics, ed. Robert B. LOUDEN (Cambridge: Cambridge University Press, 2002), 4, 6-7, 9-10, 13-14. As for the term consciousness, it can for Schleiermacher refer to that lower grade of confused "awareness" which characterizes sub-human organisms, as well as the very early stages of psychological development in the human individual $(\$ 5.1$; CG 1 41-2 [CF 18-9]), but it most properly refers to the receptive awareness of the integral and mature human being (i.e. one capable of a clear distinction of self and world, subject and object), and is divided into two forms: knowing and feeling (\$3.3; CG II 25 [CG 81). Knowing is object-consciousness, while feeling is immediate self-consciousness, and it is with the God-consciousness always inherent in the latter that Schleiermacher is particularly 
II.

Why is it only possible to speak of God's existence "in" the world on the basis of the presence in the world of reason or consciousness? Schleiermacher begins with the obvious point that God's omnipresence makes impossible any literal notion that God's existence is somehow spatially distributed in an uneven way through the created realm. And yet it will be recalled from the discussions of the First Part of the Christian Faith that our consciousness of God takes the form of an apprehension of the sheer, pure causality always presupposed not just by our own activity as a finite cause, but by the entire interconnected network of finite causality (the so-called "nature-system"), a network in which we increasingly perceive ourselves to be embedded the more our self-consciousness develops and refines itself. Would this not mean that our consciousness would inevitably "see" God as more present where finite activity was more intense, where the balance between active and passive states tilted more toward the active side, thereby introducing a variance in divine presence which would undermine the doctrine of omnipresence? Schleiermacher admits this is true, but, borrowing an idea from classical patristic thought in the person of John Damascene, he says that this more "intense" presence of God signals no spatial distinction in the divine causality itself, but only a distinction in the "receptivity" of finite being. In other words, it is precisely the more "active" finite causality which is for that very reason the more "receptive" of the absolute causality of God, the more open or transparent to it. As the first edition discussion helpfully clarifies, the language of God's existence "in" any finite thing is tantamount to saying that God's existence is "announcing itself" in that thing; that is, God's existence is not really "more" in one place than another, but it is more decisively revealed in one place than another. ${ }^{8}$

But Schleiermacher admits this realization only gets one so far, since it would seem that no finite thing in itself could have the kind of transparency which might lead us to see in it a true divine presence, a "revelation" of God's existence which amounted to a genuine existence of God "in" it.

concerned when he identifies the place within nature where God can truly appear and, under optimal conditions (i.e. in the Redeemer), even "dwell". The successive specifications are made clear in the passage from the Glaubenslehre under analysis: he distinguishes in the natural world first the level of the unconscious, then the level of the conscious but unintelligent (i.e. the irrational or animal consciousness), then the level of the human being as rational conscious individual ( $\$ 94.2$; CG II 55 [CF 387]). Hence, in what follows, the phrase "rational consciousness" should be taken to refer to mature human self-awareness in distinction from the nonconscious, and from lower forms of animate awareness.

${ }^{8}$ Friedrich Schleiermacher, Der christliche Glaube. Erste Auflage (1821/22), in Kritische Gesamtausgabe, ed. by Hans-Joachim BIRKNER et al., vols. I/7.1 and I/7.2, ed. by Hermann Peiter (Berlin/New York: Walter de Gruyter, 1980), here: I7.2, 29. Further references to the first edition will be cited in footnotes, abbreviated as $K G A$, followed by the volume number and page. 
This is because God can only be conceived as "pure activity", a crucial point for all that follows. Schleiermacher is saying in effect that God is only revealed "in" the world where absolute causality appears, causality totally determining the finite but itself in no way exposed to reciprocal conditioning. Of course, this immediately presents an obstacle for any talk about a distinct finite thing "revealing" God or being a locus of God's existence. Schleiermacher has earlier insisted that all finite things are in themselves constituted by an interconnection and interplay of active and passive states. And the passive aspect of any finite particular is not merely the term of a relationship whose other term is the activity of some other individual finite (\$51.1; CG I 309 [CF 201]); properly understood it corresponds rather to the activity of the total interconnected pattern of cause and effect constituting the world. That is, every individual thing is always conditioned by "everything else", by the universal nature-system itself $(\$ 46.1-2 ; C G$ I 264-71 [CF 170-5]).

What is the result? On the one hand, God can only be said to "exist in" the world where a causal activity appears which totally conditions the finite, with no reciprocal being-conditioned. On the other hand, any isolated finite individual within the world is always a site of confluence for active and passive relations with other finite individuals. The upshot is that in no finite thing in isolation could the total and pure causal influence of God so manifest itself as to justify speaking of that thing as a self-announcement or presence of the creative existence itself. Rather, God can only appear as the power conditioning the total interconnected system of finite causal interplay as a whole. Hence Schleiermacher's preliminary summation: "there is, so far, no existence of God in any individual thing, but only an existence of God in the world" ( $\$ 94.2$ CG II 55 [CF 387]). Readers will once again recognize in this statement merely a concentrated recollection of conclusions drawn earlier in the Christian Faith, such as that the divine causality can only be conceived as equal in scope to the totality of finite causality ( $\$ 51.1$; CG I 309 [CF 201]), or that the world as a whole should be considered by piety to be a complete revelation of the divine creative power ( $\$ 57.1$; CG I 359 [CF 234]).

But this is obviously not the end of the story, for if the world as a whole is supposed to "reveal" God, the question arises, where in the world does this revelation happen, and to whom? The difficulty can be stated this way: even if there is an existence of God "in" the world as a whole, in the previously stipulated sense that God's omnipotence "announces" itself there, then this would have inner-worldly relevance only if the world as world were to "appear" somewhere within the world. And this is in fact the significance of Schleiermacher's next statements, those concerning the presence within the world of human being as rational consciousness. For though it was determined above that no isolated finite thing could reveal God's pure causality, could this stricture not be evaded if that finite thing were not isolated, if it were, at least in principle, a point of interconnection 
with everything else - if it were, in short, that point in the world where the world appeared? But this is just what rational consciousness amounts to for Schleiermacher.

It will be recalled from the introduction to the Christian Faith that consciousness is defined by the conjunction of living receptivity and free self-activity; these make their appearance in the human subject's selfawareness, that is, in immediate self-consciousness or Gefübl, in the form of feelings of dependence and freedom (\$ 4.1-2; CG I 32-7 [CF 13-15]). Schleiermacher makes it clear that the living subject does not receive influences from causes outside itself in a "purely passive" manner, but rather is actively passive, so to speak. In other words, what defines subjective life or spirit is the very act of continually taking up these external influences into itself, bringing them into its self-constitution moment by moment so that they always become data for its own consequent self-expressions in thought and deed. "Receptivity" is thus about how our subjective "selfactivity", the ensemble of our thinking and active existence, is at the same time the free response to, the reflection or "processing" of, the totality of external forces which have always already conditioned and "placed" us.

Note the phrase "at the same time": the subject's level of receptivity and its level of self-activity are emphatically not competing or inverselyrelated quantities. Conscious life is more intense to the degree that both receptivity and self-activity extend their scope with regard to all that is beyond the subject ( $\$ 122.1$; CG II 284 [CF 566]). It is precisely the mark of intelligent or rational consciousness that this power of "extension" is, at least in principle, at a maximum. For rational self-consciousness is marked by the ability not just to receive and freely react to influences; the more it is developed, the more it comes to see the interconnection of all finite influences on itself and on each other, and hence the more it comes to regard all of finite reality as a systematic whole, including itself as an integral part. This is the point of phrases like "the whole system of nature or the world exists in our self-consciousness" and "is seated in the spirit as its original possession" ( $\$ 34.1$; CG I 213 [CF 138]). And of course it is just reason's capacity for this kind of consciousness-of-world which Schleiermacher closely associates with its potential for consciousness-of-God, for "the equivalence of divine causality with the whole content of the finite enables every act to excite the religious consciousness, every act, that is, in which we take up into ourselves a part of the natural order or identify ourselves with such a part, every moment of our self-consciousness as it extends over the whole world" ( $\$ 53.1$; CG I 318 [CF 207]).

This notion of the development of consciousness as the mutual intensification and extension of living receptivity and free self-activity is evidently presupposed in Schleiermacher's repeated assertion that finite causality is greatest in those points of space where clear human consciousness is active (as opposed to those points where either unconscious life or “dead" forces predominate, cf. $\$ 49.1$; CG I 296-7 [CF 190-1]). It also 
begins to point toward the solution of the problem of God's existence "in" the world. For though the degree of what Schleiermacher calls "pure passivity" in a finite thing does indeed decrease as that thing's degree of activity increases, the special kind of "passivity" involved in living receptivity is not diminished but actually intensifies according to the degree of free selfactivity. And this illuminates the point made earlier about the shifting "degree" of God's presence in a specific place in spite of the necessary assertion of his omnipresence. God, as the absolute causality underlying all finite causality, is "more present" where finite causality is greatest not because of any variation in omnipresence but rather due to the variation "in the receptivity of the finite being to the causal activity of which the divine presence is related" ( $\$ 53.1$; CG I 318-19 [CF 208]).

It should now be clearer why the first stage of Schleiermacher's discussion of the incarnation, that is, of God's "existence in" Jesus Christ, should conclude that "it is only in the rational individual that an existence of God can be admitted" ( $\$ 94.2$; CG II 55 [CF 387]) and that in fact it is "only through the rational nature that the totality of finite powers can become an existence of God in the world" ( $\$ 94.2$; CG II 56 [CF 388]). Finite rational consciousness is that place in the world where God's "pure causality" can potentially be expressed and revealed, where it can "exist" quasi-locally. This is, first, because as intelligent it is capable (in principle) of grasping the systematic interconnection of all finite causes and its own co-implication with them in such a way that the true idea of God as sheer, absolute causality conditioning the whole spatio-temporal world can emerge as an object of thought. Second, this is because its living receptivity is capable (again, in principle) of an apprehension of God's absolute causality which, as "higher self-consciousness", could penetrate and control at each moment the "sensuous" or "lower self-consciousness" which mediates and gives a tone and direction to every living moment of thought and action. In these ways the living subject is able not only to represent God mentally, but to make the very texture of its existence an expression of God's reality.

III.

The presence of the qualifier "in principle" in these descriptions of human spirit indicates the final obstacle blocking the possibility of God's existence "in" the world, which in turn requires the second step in Schleiermacher's account of the incarnation. For the fact is that human godconsciousness in general, as an original capacity of the human species, does not fulfill this potential of constituting an "existence of God" in the world. Indeed it is utterly incapable of fulfilling this potential on its own power, either individually or through the "natural" evolution of the species, and this incapacity is essential, not an accidental result of individual or collective sinfulness. Even were we to postulate a "first man" before the fall into 
sin we would still be in the realm of a purely fortuitous lack of undiminished God-consciousness always hovering on the brink of failure, not the kind of essentially triumphant internal power Schleiermacher has in mind ( $\$$ 94.1; CG II 52-3 [CF 385]). Only a new creation of humanity, the consummation of a human race still essentially incomplete, and thus a new, unfathomably original miracle of direct divine power will serve here. In accordance with the ecclesial faith he cherishes, only the Redeemer, Jesus Christ, is the site of God's genuine, full creative presence "in" the world.

This is clearly not the place to summarize Schleiermacher's Christology in its entirety. The point is to focus on the rigorous sense in which he understands God's existence "in" Christ, seeing in the incarnation the salvific union of the divine being with human nature. The foregoing discussion has already set out the necessary parameters, for the miraculous implanting of a supremely powerful consciousness of God in Jesus is the actualization of that presence of God in the world which human being should be, but apart from Christ is not and will never be. Original human being suffers from a twofold deficit destined to be overcome through the incarnation. Its consciousness of God, vitiated everywhere by the sinful tendency, cannot assert itself in ways which are not "hemmed in and bent [gehemmt und gewendet]" by the lower self-consciousness. ${ }^{9}$ This means, first (recalling the twofold distinction used above), its intelligence can never completely disentangle the sheer absolute activity of God from the interactions presented to sense-consciousness, and hence (even in the sphere of the most refined non-Christian monotheisms, those of Judaism and Greek philosophy) cannot represent God in thought without materialistic confusions and unchecked anthropomorphisms. Likewise, second, because the higher self-consciousness, in which God's absolute causality is received and apprehended, is unable to gain complete mastery over the sensuous lower self-consciousness, the human self is unable to be completely determined in all its actions by the prior pure causality of God.

Triumph over this twofold failure, of course, provides the precise terms with which Schleiermacher can now define the peculiar God-consciousness of Christ. The wording of the first edition more readily reveals this structural move (which nonetheless also underlies the discussion in the second edition):

If then God is neither able to portray himself [abbilden] in us with pure and perfect suitability, nor even to establish himself [sich erweisen] as pure activity (since God's existence can only be grasped as activity): so then this is no true and genuine existence of God in us. But what constitutes the Redeemer as such can accordingly be nothing other than such a perfect indwelling of the highest being in consciousness, which can be reckoned as the pure activity of God in human nature, and in light of which we must say of the Redeemer, that God was in him in the highest sense in which God could be in an individual at all. ${ }^{10}$

9 Following the wording of the first edition: $K G A$ V/7.2, 29.

10 KGA $\mathbf{V} / 7.2,29$. 
Immediately following this passage the first edition adds a significant clarification. The phrase "in the highest sense in which God could be in an individual at all" is not intended to mitigate the assertion that God really "is" in Jesus, as if it implied that this were merely a pictorial or poetic turn of phrase. Just the opposite: it is intended to signal that the presence of God in Christ, his unity with him, should be taken in the most complete fashion conceivable, indeed more complete than the turns of phrase used suggest, inevitably containing within themselves as they do misleading images of two separate "things" coming together.

What then does Schleiermacher intend to suggest by this unity? Nothing less than this: the existence of God in him, the undiminished presence of absolute loving causality, constitutes the very inner selfhood of Jesus Christ. This is because (as we have seen) only in a finite individual with consciousness and reason could that power which totally conditions all reality replicate itself as a power totally conditioning the individual, that is, "continually and exclusively determining [that individual's] every moment" $(\mathbb{\$} 94.2$; CG II 56 [CF 388]). And only in Christ is this possibility realized. Thus God, precisely through being perfectly received in his consciousness as the total power determining the world, conditions every aspect of his human existence through time. Schleiermacher confesses that the analogy famously used by the Athanasian creed, namely that God and human being unite to form the one Jesus Christ just as the rational soul and the body unite to form a single human person, fits his intentions here precisely [" $g(e)$ rade so"] ( $\$ 96.3$ footnote; CG II 69 [CF 397]) and in fact "even if not clearly expressed, runs through the whole foregoing presentation of the subject" ( $\$ 97.4$; CG II 87 [CF 411]). To put this analogy in Schleiermacher's own terms, the innermost core of Jesus as a human self was nothing other than the pure divine activity forming the "Impuls" determining his entire conscious and active existence. Hence not just Jesus's bodily life, but his entire human actuality, body and mind, formed the "Organismus", the organic system which reflected and expressed the "Grundkraft" or fundamental force of God's genuine existence in him.

Schleiermacher's zeal here can even encompass a retrieval of the ancient doctrine of anbypostasis: the incarnation of God in this human consciousness is not a second, additional act to the "formation of human nature into the personality of Christ". No, there would have been no person "Jesus Christ" at all apart from this initial divine impartation ( $\$ 97.2 ; C G$ II 76 [CF 402]). Of course, his eagerness, searching criticisms notwithstanding, to align his own position as much as is possible with the classical orthodox consensus never displaces the fundamental role for him of the scriptural witness. In this case, Schleiermacher intends his entire discussion to be nothing but a dogmatic explication of the language of the New Testament, particularly Paul's phrase "God was in Christ" and John's "the Word became flesh" ( $\$ 96.3$; CG II 69 [CF 397]). The relevance of the first is obvious. As for the second, Schleiermacher (as is usually the case) finds 
the Johannine conception especially congenial given the right interpretation. As he reads it, "Word' is the activity of God expressed in the form of consciousness, and 'flesh' is a general expression for the organic." Thus he understands John's use of "logos" to refer to the divine activity of creation as "mediated" by a rational individual having perfect God-consciousness. For if all finite being or causality expresses the creative activity, consciousness, the highest form of finite causality we know, expresses this creative activity precisely as a timeless "word", as eternal meaning-for-consciousness. The fundamental force driving and shaping the human individual Jesus is this pure divine power itself, the power of creation taking shape within creation as consciousness; his integral humanity thus becomes the created "organ" for the new act of creation itself.

Such in brief is the substance of Schleiermacher's understanding of the incarnation, of the way God was "in" Jesus Christ. One has only to read this material in order to see the extraordinary care he took in thinking through his position; equally evident is the way in which his entire understanding of redemption is closely intertwined with this presentation of Christ's person. As noted at the beginning, he is very much aware that he is defending the legacy of the mainline reformation (itself carrying forward much of the orthodox legacy of Christian antiquity) and its official ecclesial bodies against those "separatists", whether of mystical/enthusiastic or of rationalist stripe, who repudiate the exclusive soteriological status here granted to Christ ( $\$ 121.1 ; C G$ II 278 [CF 560]). Thus the ecclesial or "churchly" doctrine of redemption puts tremendous structural weight on this notion of the "union" of the divine being with human nature in Christ.

Schleiermacher is especially sensitive to the threat presented to adequate understanding of this union by any account of Christ which sees in him an exalted superhuman or semi-divine power but which shrinks from affirming a direct conjunction with the creator. The struggle against Arianism in the fourth century was the crucible in which the early church clarified the truly divine status of Christ, and Schleiermacher sees himself compelled to honor the result of this struggle in his own dogmatic formulations, as page $\$ 123.2$; CG II 289 [CF 571] makes clear. "The Church has properly rejected ... all representations of Christ with an Arian bias." Not only does Arianism imply that our "living communion with Christ" unites the believer with something less than fully divine, it also threatens the created integrity of the human nature of Christ by fusing it with some putatively higher created nature. Either way, the Arian tendency cripples the ecclesial doctrine of redemption.

IV.

The quotation on Arianism actually comes from later in the Christian Faith, from the discussion of the Holy Spirit, even though it refers expli- 
citly back to his Christology. This is one of many tokens of the very close relationship between Schleiermacher's Christology and his Pneumatology. In discussing the latter we can be very brief. This is not because the doctrine lacks importance within Schleiermacher's system, but because its basic logic, that of a union of divine being with human nature, has already been set forth in the discussion of Christ as God incarnate. And just as evident here is the soteriological orientation which guides the way the doctrine is handled. Schleiermacher labors again and again to make clear the need for an actual presence of the divine existence "within" the world as an active locus of re-creative activity to account for the effect of redemption, namely the completion of humanity's creation through the renewed God-consciousness gaining mastery over sin. Jesus was that locus, but Jesus is now gone. What is required, then, must be another "existence" of God united with human nature, one which is enabled by the incarnation in Jesus but which now persists apart from his presence as an individual, and which communicates his special blessedness to others ( $\$ 123.2$; CG II 291 [CF 572]).

The coming of the Holy Spirit (Pentecost, to use the classical designation) inaugurates this second union of God and humanity; now God is present as the "common spirit" which animates the church, the religious community of those redeemed by Christ. As God was "in" Christ, so God must now be "in" the church in order to continue Christ's redeeming influence, in order that his "effective power" may be communicated to others ( $\$$ 116.3; CG II 243 [CF 535]). All that will be attempted here will be to show briefly how the conceptual moves which Schleiermacher used to construe the divine-human union in Christ are simply replicated with some modifications to construe the divine-human union in the Church.

The key is that now not an individual but a collective is at issue; but the equation of God's "existence in" something with the presence there of an "absolutely powerful God-consciousness" is still operative. The wording of $\$ 144$ of the first edition reveals both the parallelism and the contrast: both Jesus Christ and the Church involve "Vereinigungen" of the divine being with human nature, but in the former case this union is "personbildende" while in the latter it is "gemeinheitbildende". ${ }^{11}$ Schleiermacher explicates the collective nature of the union comprising the Holy Spirit in the following way. The Spirit is that in the redeemed which brings them together, binding them into a unity, energizing them toward more and more intensely loving fellowship, driving them to a common vision and work for God's Kingdom ( $\$ 121.1$; $C G$ II $278-80$ [CF 560-2]). The Spirit, as befits the divine presence, is always self-identical even if it manifests itself in different ways in different individuals. But there is no "possessing" of the Spirit by an individual. Each has a share in the common Spirit; they are conscious of their participation in this divine presence only as they are si-

$11 K G A 1 / 7.2,207$. 
multaneously conscious of their participation in the collective life of the church ( $\$ 123.3$; CG II 292 [CF 573]). Thus, although the Spirit indeed "prolongs" the activity of Christ through time ( $\$ 122.3$; CG II 286 [CF $568]$ ), it is quite a different "mode" of divine presence ( $\$ 125.1$; CG II 299 [CF 579]). The redeemed are no longer individual disciples of Jesus. He communicates to them only the "pure will" of "sinless perfection", but their particular acts as redeemed people in particular times and places are initiated not by Christ but by the "Gemeingeist", the collective Spirit ( $\$ 122.3 ; C G$ II 286 [CF 567-8]).

In short, the effect of the presence of the divine being in redeemed humanity is not the total formation of an individual, as it was with Jesus, but rather the formation of what Schleiermacher calls a "moral person". But this transition from individual person to collective person leaves the essential picture of divine presence intact. For a "moral person" is the formation of a group of people into an organic system with unified activity ( $\$ 116.1 ; C G$ II 241 [CF 534]). Just as Jesus' individual humanity formed the "organism" receiving and expressing the divine presence, so the collective humanity of the church likewise forms such an organism. And just as in Jesus what this organism received and expressed was nothing less than the divine being, so that God was the fundamental power or "impulse" conditioning his personal existence, so too the collective organism of the church is conditioned by the identical impulse, since the pure activity of God is always self-identical ( $\$ 125.1$; CG II 299 [CF 579]).

A final point about Schleiermacher's pneumatology is in order, the importance of which will become clear in the last section of this paper. Although it is Christ who first makes possible the gathering of the church and the communication of the Holy Spirit, Schleiermacher insists that the union of divine and human involved in the latter is not of lesser status, but is to be reckoned as a divine "existence in" the world in precisely the same deep sense that he has outlined with regard to the incarnation. As suggested above, the anti-Arian thrust of his argument is just as much in play in his pneumatology as in his Christology. This is clear both from the side of the divine "impulse", and from the side of the human "organism" which is its receptacle. In Jesus the divine being formed his innermost self; this "inwardness" is the mark of the "absolutely powerful" nature of his God-consciousness, which in turn is equivalent to God's existence "in" him in the proper sense. To be "inward" or "innermost" in the human self is another way of indicating the "fundamental" status for personal existence of the force in question, its power as an unvitiated higher consciousness to condition all thought and activity. But the very same "sinless perfection and blessedness" of Christ, the same "absolute and continuous willing of the Kingdom of God", is secondarily the "innermost impulse" of the redeemed individual, albeit only insofar as it is already and primarily the common spirit of the whole church in which the Christian participates $(\$ 116.3 ; C G$ II 244 [CF 535-6]). The result is that, even though conditioned by Christ 
and present only in all the redeemed collectively insofar as they form one organic body, the divine presence in the Church is no less than that in Christ: "in virtue of its inwardness, it is in the whole an absolutely powerful God-consciousness, and thus the existence of God therein" $(\mathbb{\$ 1 1 6 . 3}$; CG II 244 [CF 536]).

In the second place, it was seen that the incarnation involves a "reception" of this "quasi-local existence" of the divine being, an organism sufficient for or adequate to the pure act of the divine "impulse". This organism was, of course, the individual human being Jesus. Turning again to the church, it is true that no individual human being among the redeemed constitutes such an adequate vehicle of the divine presence. Sin always remains as a rival force in the individual, a power which decisively shaped the individual before the advent of redemption and which is, afterwards, a continuing source of resistance to be overcome. Hence those aspects of any individual human being which are brought into obedience to the higher consciousness represent only small fragments of the redemption of the total reality of humanity. But together, as the whole church in space and time, the redeemed amount to "the sum-total of all the forms of spiritual life based on the varieties of natural foundation", mutually and reciprocally correcting their individual deficiencies ( $\$ 125.1$; CG II 301 [CF 580]). So Christ, as an original act of unimpaired human nature, represented the total aggregate of human powers "taken up into unity with the divine principle"; and so, too, the church as a true common life unifies the same aggregate of human powers ruled and directed as a whole by the Godconsciousness ( $\$ 125.1$; CG II 299 [CF 579]). Thus the church is the collective image (Abbild) of Christ in a way that the individual Christian cannot be ( $\$ 125.1$; CG II 299 [CF 579]); or rather, to be more precise, "the Church only gradually attains to be the perfect image of Christ" $(\$ 125.2$; CG II 302 [CF 581]).

V.

Enough has been said to show that an identical logic of divine-human union is operative in Schleiermacher's understanding both of the person of Christ and of the communication of the Holy Spirit. It remains to show, in this section, how the foregoing discussions provide the key to understanding the famous (or infamous) "Conclusion" to the Christian Faith which contains Schleiermacher's discussion of the idea of God as Trinity. As with the passages already examined, this is a rich and fascinating albeit complex and tantalizingly brief section; what follows is designed only to provide a preliminary orientation to these few pages, not to summarize them exhaustively. Two questions are of concern in this "Conclusion". First, how Schleiermacher understands the nature and function of the doctrine of the Trinity, and second, what he believes the Christian Faith has contributed 
to its more adequate formulation for the present time. This section is concerned with the first.

One must obviously begin with the ringing claim of the proposition with which $\$ 170$ opens: "All that is essential in this Second Aspect of the Second Part of our exposition is also posited in what is essential in the doctrine of the Trinity" (CG II 514 [CF 738]). He is referring to the entire massive treatment of grace which takes up over half of his dogmatic treatise; the essence of the doctrine of the Trinity and the essence of Schleiermacher's entire soteriology, in fact the heart of his dogmatics, are one and the same. (Thus, properly speaking, the discussion of the Trinity is the "conclusion" not to the Christian Faith as a whole, but to the second aspect of the second part, the doctrine of grace or redemption.) This is not surprising, since as he immediately reminds the reader the twofold union of the divine being with human nature (through the selfhood of Christ and through the collective spirit of the church) is "essential" to his entire treatment of Christian redemption. It need only be recalled how the entire structure of his soteriology unfolds, so to speak, from the treatment of Christ's person. For the content of the section on the work of Christ is identical with the content of the section on his person, only the point of view being different. (This is the argument of $\$ 92$.) And in turn not only the following division on salvation in the individual but also the whole second section on the origin, subsistence and consummation of the church are to be regarded as "that which came to pass through" the Christ whose person and work are so carefully laid out beforehand ( $\$ 92.3$; CG II 41 [CF 376]). Finally, there is the striking claim that the full treatment of the operations of the Holy Spirit cannot be limited to an account of the way it is a divine union with human nature; the latter provides only a formal schema, whose content is only filled out by the extensive treatment of the subsistence of the church, including the doctrines of scripture, ministry, the sacraments, etc $(\$ 123.1$; CG II 288 [CF 569]).

So "the whole view of Christianity set forth in our Church stands and falls" with the proper affirmation of the two saving unions of God with humanity ( $\$ 170.1$; CG II 515 [CF 738]). But if the latter forms the heart of Schleiermacher's treatment of grace, what does the doctrine of the Trinity itself add to what has already been said at such length? What is distinctive about the doctrine of the Trinity is not so much a matter of its content as of its function and form. Its function is defensive; the doctrine originally "established itself in defence of the position that in Christ there was present nothing less than the Divine being, which also indwells the Christian Church as its common Spirit, and that we take these expressions in no reduced or sheerly artificial sense" ( $\$ 170.1$; CG II 515 [CF 738]). Thus the doctrine of the Trinity should act as a prophylaxis against any fatal Arian dilutions of the church's confession of God's saving conjunctions with humanity in salvation history. Just how seriously Schleiermacher takes this function is suggested by his architectural image of the doctrine 
as the keystone (Schlußstein) of Christian doctrine ( $\$ 170.1$; CG II 516 [CF 739]). The keystone is the topmost central piece that joins the two sides of an arch and hence completes it. This makes sense in light of the doctrine's defensive function: it does not form the substance of the arch but it does anchor its structurally crucial point, enabling it to maintain its shape.

What form must this doctrine take, then, which will allow it to serve its function? It is obviously not to be simply a repetition of the entire soteriology or even of the doctrines of the divine unions with humanity constituting Christ and the church expounded earlier in the dogmatic treatise. The keystone image may prove helpful again here; the keystone's function of serving as the central joint or point of connection for the sides of the arch is possible due to its unique shape which allows it to receive and connect both its sides, holding them together in symmetrical alignment. In like manner, the function of safeguarding redemption through the divine unions will require the doctrine of the Trinity to take on a "combining and connecting [zusammenstellende und verknüpfende]" structure, one which allows it to bring into a synoptic coordination the assertions dispersed throughout the dogmatics concerning the divine being itself and its modes of "presence" in the world which we have previously discussed. ${ }^{12}$ In Schleiermacher's words, the doctrine will have to take the form of "defin [ing] this peculiar existence of God in that which is other, in its relation both to the existence of God in Himself and to the existence of God in relation to the world in general" ( $\$ 172.1$; CG II 528 [CF 748]).

Thus three sorts of dogmatic utterance about God's being or existence (first in the world as it creative source, second in Christ, and third in the church) are to be aligned with one another in order to show their intelligibility and convergence upon a common divine referent. "Gleichstellen" is the key verb for understanding the doctrine of the Trinity; it must enable the three kinds of talk about the divine "Wesen" to form a network of representations or expressions which are mutually equated and identified with reference to one another. But this is not in order to add a new doctrine about God; it is rather the various facets of the doctrine of redemption which are hereby interconnected. In order to summarize, in the concluding section of this paper, what Schleiermacher thought his dogmatics had contributed toward restating the doctrine of the Trinity for his own day, the remainder of this section will have to briefly sketch the task he thought confronted the dogmatician in this area.

The task is essentially defined by Schleiermacher's critique $(\$ 171$; CG II 519-27 [CF 742-7]) of the received orthodox formulae of Trinitar-

12 The phrase quoted comes from the first edition: KGA I/7.2, 359. Schleiermacher similarly says that the doctrine of the Trinity provides the drawing together or combination (Zusammenstellen) of the relationships of union between the divine being and human nature whose content is fully discussed in the doctrines of the incarnation and of the sending of the Holy Spirit ( $\$ 123.1 ; C G$ II 288 [CF 569-70]). 
ian doctrine (a critique which is, of course, closely connected with the historical interpretations developed in his 1822 essay "On the opposition between the Sabellian and the Athanasian Representation of the Trinity"). ${ }^{13}$ In outline and leaving aside many details, the story he tells goes like this. In the polemical heat of various controversies during the early centuries of the church those theorists of the Trinity who later came to be accepted as orthodox felt compelled to trace God's unions with Christ and the church back to certain eternally separate subsistences within God's being. And in turn, the concept thereby developed of an eternal "Son" prior to the incarnation seemed to demand that the one he called his "Father" should also (retroactively, as it were) be accorded the status of a "person" in order to avoid the specter of subordinationism. These two moves, as Schleiermacher sees it, smuggled a serious incoherence into the heart of the classical doctrine of the Trinity.

That incoherence meant that even though the doctrine has indeed performed the necessary function allotted to it, this has come at a high cost. Orthodox Trinitarian thought quite properly sought to equate the status of the divine being in itself with that of the divine presences in Christ and the church. Failure to affirm this would have been fatal to the Christian doctrine of redemption, since it would have called into question its central confession: that the living fellowship of Christians with Jesus Christ and their participation in the Holy Spirit are in the strictest sense nothing other than their fellowship with God. But the twofold presupposition (eternally separate subsistences, one of them being the Father/creator) blocked any consistent and perspicuous intellectual representation of the divine triunity. Distorted by that prior decision, the doctrine's necessary function could only be served through a dubious insistence, on the one hand, that the three persons were equal in status to each other, and, on the other hand, that the three persons were equal in status to the single divine being. Schleiermacher acknowledges that the church was quite right to zealously defend these affirmations, granted the twofold assumption (\$171.1; CG II 521 [CF 742-3]). But it simply could not reduce the different elements demanding acceptance to conceptual coherence, thus rendering unavoidable continuing oscillations which called into question either the unity of God or the truly divine status of Jesus ( $\$ 171.3$; CG II 522-24 [CF 744-5]).

Even worse, this orthodox Trinitarian formula, with its unavoidably speculative elements, was not only fixed as a measure of faithfulness to the Christian church; its terminology was also introduced into the parallel attempts of the early teachers to clarify the divine status of Jesus and the Spirit. The great theological achievements in this latter sphere were basic

13 Friedrich Schleiermacher, "Über den Gegensatz zwischen der Sabellianischen und der Athanasianischen Vorstellung von der Trinität," in Kritische Gesamtausgabe, ed. by Hans-Joachim BirKNer etal., vol. I/10, ed. by Hans-Friedrich Traulsen (Berlin/New York: de Gruyter, 1990), 223-306. 
to Christian self-understanding, but not only were the formulations of Christology and pneumatology now "infected" by the speculative elements in the Trinitarian scheme, the very success of these formulations made it unthinkable to recast the Trinitarian dogma lest the more fundamental insights into the divinity of Christ and the Spirit thereby be undermined as well ( $\$ 172.2$; CG II 529 [CF 748]). This reading of the situation provides the backdrop for Schleiermacher's understanding of his own contribution.

\section{VI.}

The parroted complaint, mentioned at the beginning of this paper, about the supposed denigration of the doctrine of the Trinity involved in Schleiermacher's "relegation of the dogma to an appendix" is a good place to begin. For it is striking that just this positioning (Stellung) of the discussion of the Trinity at the end of the dogmatic treatise is seen by Schleiermacher as part of his most important contribution to its reconstruction and revival ( $\$ 172.3$; CG II 530 [CF 749]). For as the discussion of its form and function should already have made clear, the Trinity, its importance notwithstanding, is not a primary doctrine, not a "Glaubenslebre"

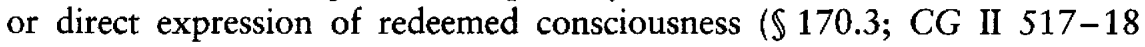
[CF 740-1]). It is instead what might be called a "second-order" doctrine, which presupposes the first-order doctrines of God's existence in Christ and in the church. Ironically, Schleiermacher claims that the doctrine of the Trinity can only be rescued or resuscitated for the present once dogmatics has provided reformulations of Christology and pneumatology which render them intelligible in contemporary terms, and which avoid entanglement with the standard Trinitarian terminology. Only after these more fundamental positions are secured can the dogmatician approach again the Trinitarian formulae themselves without fear that subjecting the latter to critique and reconstruction will endanger the former $(\$ 172.3 ; C G$ II 530 [CF 749]).

At the heart of the doctrine of the Trinity lies the same content that lies at the heart of the doctrines of Christology and pneumatology: the conceptualization of God's very presence in Jesus and in the church. But in the latter doctrines this common content is handled "on the side turned toward the immediate interest of faith" ( $\$ 172.2$; CG II 529 [CF 748]); in the doctrine of the Trinity, by contrast, with its coordinating and defensive function in view, this content is conceptually developed with an eye to delivering greater dialectical precision ("more exact definitions" as Schleierma-

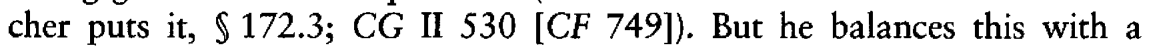
warning. Because the church dogmatician can have no fixed and final formulation of God's being "in itself" or of God's relation to the world, but can only construct these "ad hoc" by borrowing schemes from contemporary philosophy, both the precision and the permanence of any Trinitarian 
representation thereby formulated will always be strictly limited $(\mathbb{1 7 2 . 1 \text { ; }}$ CG II 528 [CF 748]). We can only strive for the formulae which best safeguard what is essential, cognizant of the inevitable anthropomorphisms involved, and aware that our attempts cannot claim to represent a permanent and irrevocable advance in the ecclesial community's grasp of the faith.

With these constraints firmly in mind, Schleiermacher believes that his doctrinal reformulations of divine presence in Christ and church have laid the groundwork for a consistent rethinking of the Trinity. But he admits that the actual reconstruction of the doctrine remains to be done, and that he cannot undertake that in his own treatise ( $\$ 172.3$; CG II 531-31 [CF $750-51])$. The reason is that though the conceptual space has now been cleared for it by his dogmatic labors in Christology and pneumatology, the next steps must rest with the New Testament exegete. For only exegesis will tell us if the self-representations of Christ and the apostolic witness concerning him recorded in scripture really demand the positing of eternal separations in God. If they do, then there is nothing for it but to throw the ball back to the dogmatician, who must see if some better formulae can be found which avoid the incoherences already indicated. But if exegesis should turn out to leave the matter open (and the tenor of the whole discussion, as well as his 1822 essay, leave little doubt that this is Schleiermacher's opinion), then dogmatics will be free to adopt a more "Sabellian" understanding of the Trinity, abandoning those speculative and troublesome "separations". This will protect what is essential to the Christian understanding of redemption, the divine existence in Christ and the church, without falling into the classical doctrine's problematic "dualism" of a single being over against three persons. ${ }^{14}$

So much, then, for Schleiermacher's own thoughts as to what he had accomplished. In light of the brilliance and insight of his approach, a serious critical assessment from a contemporary perspective would have to be detailed and nuanced, and any such attempt would be welcome were it to occur within the context of a close engagement with Schleiermacher's actual detailed proposals on the Trinity within the context of his whole dogmatic scheme. The preceding paper has provided only some preliminary gestures toward this important work, but enough has been said to suggest some very brief and tentative judgments as to the deficits and promise of Schleiermacher's way of thinking about the Trinity. The greatest weakness here is surely the flat rejection of any notion of triune personhood imma-

14 In light of this discussion it is perhaps significant that Schleiermacher chose to use for the title of his concluding section the term Dreibeit (literally, 'threeness') rather than the term Dreieinigkeit (triunity). For the latter more strongly connotes that historic dualism of oneness over against threeness which he seeks evade ( $\$ 170.2$; CG II 516 [CF 739]) while the former is more neutral. 
nent within the eternal being of the creator. Developing a counter-position would have to operate on three fronts.

First, his astute critique of the incoherence and dogmatic inadequacy of the "ecclesiastical" doctrine, i.e. Nicene orthodoxy, would have to be answered, and the historical reconstruction of the lineages of the "Athanasian" and "Sabellian" notions of the Trinity which bolster that critique would have to be probed. Second, those assumptions about the sources and limits of dogmatic language which he allows to constrain Trinitarian discourse would have to be confronted by an alternative scheme. Third and perhaps most important, the entire soteriological framework within which his notion of the Trinity reflects and codifies, especially assumptions regarding the nature of human being and of the final human telos or good with respect to the World and to God, would have to be interrogated. ${ }^{15}$

The questions which must be put to Schleiermacher's conception in these areas are serious and far-reaching, but they do not cancel out his penetrating insights, two of which can be mentioned which might be especially fruitful for shifting the terms of contemporary Trinitarian discussion. The first insight is by no means unique to Schleiermacher. Karl Rahner, beginning with his seminal 1960 essay, was well-known for his insistence that the centrality and relevance of the Trinitarian dogma could only be rediscovered by discerning at its core the very structure of Christian redemption itself, the historical "economy" of God's presence in Christ and the church which was the key to its true and original status as a "Heilslebre", a salvation-doctrine. ${ }^{16}$ At just this point one can freely acknowledge that Schleiermacher's basic instincts concerning this doctrine went straight to the heart of the matter. Dogmatics must continually relocate the complexities of trinitarian conceptualization in their original fertile ground in the religious experience of Christian practitioners: saving reconciliation with God through communion with Christ in his Spirit-filled body (i.e. the church community itself). Many theologians would no doubt eagerly acknowledge the need to recover the original role of Trinitarian doctrine as the "grammar" of the three-fold economy of Christian redemptive history, but the delicacy, detail and fruitfulness in that operation which Schleiermacher achieved, once recognized, must remain a persistent model and challenge.

15 I have elsewhere offered some preliminary reflections on this third point. Paul DEHART, "Absolute Dependence or Infinite Desire? Comparing Soteriological Themes in Schleiermacher and Kierkegaard," in Schleiermacher und Kierkegaard: Subjektivität und Wabrheit: Akten des Schleiermacher-Kierkegaard Kongresses in Kopenhagen, Oktober 2003, ed. by Niels Jørgen CAPpelørN/Richard Crouter/Theodor Jørgensen/Claus Osthóvener (Berlin/New York: de Gruyter, 2006), 561-576.

16 Karl RAHNER, "Remarks on the dogmatic treatise 'De Trinitate", in Theological Investigations, Volume IV (London: Darton, Longman \& Todd, 1966), 77-102. 
The second source of illumination to be found in Schleiermacher's discussion of the Trinity follows closely on the first, for he never forgot to situate, with a conceptual rigor which recalls the great scholastics, the "economies" of divine-human union which inform his conception of the doctrine within the austere framework of the radical otherness of God's creative act, the unimaginable asymmetry of the relation between God as source and world as sourced. One of the dangers threatening a direct retrieval of classical Trinitarian discourse and its elaboration under contemporary conditions of theological thought, such as has been underway since the latter part of the last century, is that the role and meaning of its language can easily become detached from the broader pattern of soteriological, epistemological and metaphysical assumptions within which it functioned during the patristic and medieval period. The temptation arises, for example, to conceptualize the Trinity in isolation from the theology of creation, or else to force an ersatz theology of creation directly from some preferred Trinitarian model.

The resulting failure to make the radical otherness of God's creative act a central datum within all apprehension of the divine can result in an almost gnostic fetishization of special revelation and a tension between creation and redemption. Equally problematic, the concomitant forgetting of the limits of human knowledge and language about God opens the door to a profusion of undisciplined and quasi-mythical literalizations of the trinitarian idea of "personhood." Hence the proliferation of "social" trinities and other similar instances of speculative phantasmagoria. Amid this overluxuriant growth of trinity-talk, renewed consideration of the cool and almost "classical" dialectic structuring Schleiermacher's own approach to the trinitarian problem (the integration of God's redemptive act firmly within God's creative grounding of the finite order, and the insistent submission of the Trinitarian imagination to the disciplines of intellection which follow from the radicality of that grounding relation) provides a salutary refreshment. The restraint and brevity of Schleiermacher's Trinitarian treatise alltoo-easily suggest merely another exercise in submitting the dogmatic tradition to modernist critical negation; the right shift in perspective might find in it something akin to the humble submission of our language of God's threefold identity to the strictures of apophatic negation, and consequently a modern recall to something quite traditional after all.

\section{SUMMARY}

The brief coda devoted to the Trinity in Schleiermacher's The Christian Faith does not intend to marginalize the doctrine. It indicates that the doctrine, though at present still to be completed, is the recapitulation of the entire scheme of redemption. The central structuring concept in that scheme is that of the genuine union between the divine existence of the infinite creator and human nature in Christ, a pattern replicated in the coming of the Holy Spirit as the inauguration of a second, strictly analogous union of God and humanity. The subtle way in 
which Schleiermacher conceives these unions in line with his rigorous understanding of radical causality of divine creation requires careful unpacking. Only such an analysis brings to light the architecture of the doctrine of the Trinity, and its function as a kind of meta-doctrine, connecting and coordinating different elements in the doctrine of grace.

\section{ZUSAMMENFASSUNG}

Die kurze Koda in Schleiermachers Der christliche Glaube, die die Trinitär behandelt, beabsichtigt nicht, die Lehre zu marginalisieren. Sie deutet eher an, dass die Lehre, obwohl gegenwärtig noch nicht vervollkommnet, die Rekapitulation des ganzen Erlösungsschemas ist. Der strukturierende Zentralbegriff dieses Schemas ist die genuine Einigung des unendlichen Seins des Schöpfers mit der menschlichen Natur in Christus. Die Ankunft des Heiligen Geistes wiederholt dieses Muster, insofern sie die Einführung einer zweiten, wenn auch analogen Einigung von Gottheit und Menschheit ist. Eine sorgfältige Analyse ist notwendig, um den raffinierten Zusammenhang zwischen diesem Einigungsbegriff und Schleiermachers striktem Verständnis der radikalen Kausalität der göttlichen Schöpfung zu beschreiben. Nur eine solche Analyse erklärt den Aufbau der Trinitätslehre und ihre Funktion als Metalehre, die die verschiedenen Bestandteile der Gnadenlehre Schleiermachers verknüpft und koordiniert. 